\title{
Analyzing effect of altitudinal variation in Enzymatic antioxidants of Coleus forskohlii from Uttarakhand, India
}

\author{
Pawan Singh Rana and Pooja Saklani \\ Department of Biotechnology \\ HNB Garhwal University, Srinagar Garhwal-246174 \\ Uttarakhad, India \\ Email-poojasaklani@rediffmail.com
}

\begin{abstract}
Enzymatic antioxidant activity of the five populations of the medicinal plant Coleus forskohlii from five locations of varied altitudes was assayed to analyze the effect of altitude on the enzymatic antioxidant potential. The various enzymes assayed were SOD, CAT, POD, PPO, APX and GR. Highest activity for all the enzymes was observed at higher altitudes. Strong positive correlation was observed between the protein content, enzyme activities and altitude. CAT, POD and GR activity increases significantly with the altitude while SOD was least affected. APX and PPO shows positive correlation. High activity of all these enzymes seems to be to combat the high oxidative stress at higher altitudes. Results of the present study suggest that Coleus forskohlii population growing at a higher altitude has higher antioxidant potential than those at lower altitude. Thus, the population of Coleus forskohlii from a higher altitude can be used as a source of antioxidants and for commercial propagation.
\end{abstract}

\section{Key words}

Coleus forskohlii; Enzymatic antioxidant; altitude; oxidative stress

\section{Introduction}

Environmental factors like temperature, atmospheric pressure and light radiation changes readily with the elevation. At higher altitudes low temperature, enhanced UV radiation and low atmospheric pressure pose serious environmental stresses to the plant growing in the environment (Barry, 1992). High light intensities at higher altitudes leads to accumulation of reactive oxygen species (ROS) that can induce protein damage, lipid peroxidation, enzyme inactivation and cell death (Moller et al., 2007; Latemona et al., 2013 ;) To survive such stresses plants growing under these conditions develops some changes in their physiology that includes osmoregulation, hormone level, cell membrane saturation and antioxidant defense (Huang et al., 2014). Adaptability is a long term evolutionary process and the plants growing in such environment supposed to have differences from their counterparts growing at a lower altitude. Enzymes forms main component of antioxidant defense system, these include 
Superoxide dismutase (SOD), Peroxidase (POD), Catalase (CAT), Ascorbate peroxidase (APX), Polyphenol oxidase (PPO) and Glutathione reductase (GR) (Noctor et al., 1998). All these enzymes help in maintaining the redox state of plant cells by decomposing $\mathrm{H}_{2} \mathrm{O}_{2}$, superoxide anions and other free radicals (Cho et al., 2005). Under stress conditions of higher altitudes, an increase in activity of these enzymes is possible in order to combat the reactive oxygen species produced. Enhanced activity of antioxidant defense in plant under various environmental stresses have been studied by many workers (Zaefyzadeh et al., 2009; Chen et al., 2010).

Coleus forskohlii is an important medicinal plant grows in wide range of altitudes from 600-2300m (Chandel and Sharma, 1997). The plant is well described in Ayurveda for its medicinal properties and is endemic to India (Valdes et al., 1987; Patil et al., 2001). It grows wild in the Himalayan region and can be seen easily on the dry barren hills, wasteland and agricultural fields (Kurian and Sankar, 2007). Coleus forskohlii is widely used in the Indian subcontinent and many countries against various ailments. It is used as emmenagouge, cough expectorant and diuretic in Africa, in treating intestinal and stomach disorders in Brazil and in treatment of cardiac disorders, insomnia, convulsions and respiratory disorders in India (Valdes et al., 1987; Ammon and Muller, 1985). Coleus forskohlii also claimed to possess antioxidant activities as well (Khatun et al., 2011) Thus, considering the medicinal value and wide growth range, the present study was undertaken to study the enzymatic potential of five coleus populations collected from different altitudes.

\section{Material and Methods}

\section{Plant material}

The fresh leaf samples of Coleus forskohlii were collected from five selected locations of varying altitudes from Garhwal region of Uttarakhand, India. The leaves were washed with tap water and kept in thermal proof boxes containing ice packs to ensure the freshness and taken to lab.

\section{Total protein and Enzymatic antioxidant activity estimation}

Approximately $0.5 \mathrm{mg}$ of fresh leaves were ground in 50mM Sodium Phosphate buffer ( $\mathrm{pH} 7.8$ ) containing 1\% polyvinylpyrrolidone (PVP), the homogenate so obtained was centrifuged at $12000 \mathrm{~g}$ for 15 minutes. The supernatant was diluted to $20 \mathrm{ml}$ for protein estimation and 
enzymatic assays. The protein content was assayed by Lowry's method using Bovine Serum albumin as standard.

\section{Superoxide dismutase}

Superoxide dismutase activity was assayed by the method described by Misra and Fridovich (1972). Inhibition of Nitroblue tetrazolium reduction by the enzyme was observed using spectrophotometer. The assay volume $(3 \mathrm{ml})$ contained $50 \mathrm{mM}$ potassium phosphate buffer, $45 \mu \mathrm{M}$ Methionine, $84 \mu \mathrm{M}$ NBT, $5.3 \mu \mathrm{M}$ Riboflavin and $20 \mu \mathrm{M}$ potassium cyanide. Enzyme extract $(0.3 \mathrm{ml})$ was added to the experimental tube and all the test tubes were incubated at $25^{\circ} \mathrm{C}$ Further all the tubes were exposed to fluorescent light for $10 \mathrm{~min}$. The reduced NBT was observed in spectrophotometer at $600 \mathrm{~nm}$. One unit of enzyme activity was defined as amount of enzyme required for $50 \%$ inhibition of the reduction of NBT and it was expressed as Units $\mathrm{mg}^{-1}$ protein.

\section{Catalase}

Catalase activity was assayed by using the method described by Luck (1974). The decomposition of hydrogen peroxide by catalase lead to decrease in absorbance which is read in spectrophotometer $(240 \mathrm{~nm})$. The enzyme extract $(0.2 \mathrm{ml})$ in phosphate buffer $(0.67 \mathrm{M}, \mathrm{pH} 7)$ was observed at $240 \mathrm{~nm}$ as control and the experimental test tube was added with Hydrogen peroxide. The time required $(\Delta t)$ for decrease in absorbance from 0.45 to 0.40 was recorded. The time so noted was used for calculation of catalase enzyme activity. The values were expressed as Units $\mathrm{mg}^{-1}$ protein.

\section{Peroxidase}

Peroxidase activity was assayed by the method described by Putter (1974). Guaiacol (20mM was used as a substrate and its reaction with hydrogen peroxide $(12.3 \mathrm{mM})$ is catalyzed by peroxidase. $1 \mathrm{gm}$ of plant tissue was crushed with $3 \mathrm{ml}$ of $0.1 \mathrm{M}$ phosphate buffer and centrifuged at $18000 \mathrm{~g}$ for $15 \mathrm{~min}$. The supernatant was used as enzyme extract for assay. Phosphate buffer solution ( $3 \mathrm{ml}$ ) was added with $0.05 \mathrm{ml}$ of Guaiacol, $0.03 \mathrm{ml}$ of $\mathrm{H}_{2} \mathrm{O}_{2}$ and $0.1 \mathrm{ml}$ of enzyme. The solution was mixed well and left at room temperature for $1 \mathrm{~min}$. The absorbance of assay mixture was observed in a spectrophotometer at $436 \mathrm{~nm}$ and the time $(\Delta \mathrm{t})$ to increase the absorbance by 0.1 was noted. The enzyme activity was expressed as Units $\mathrm{L}^{-1}$. 


\section{Polyphenol oxidase}

The polyphenol oxidase activity was assayed by the method of Esterbauer et al., (1977). The change in absorbance due to oxidation of Catechol was recoded at $495 \mathrm{~nm}$. Enzyme extract $(0.2 \mathrm{ml})$ was mixed with the reaction mixture containing $2.5 \mathrm{ml}$ of $0.1 \mathrm{M}$ phosphate buffer and $0.3 \mathrm{ml}$ of $0.01 \mathrm{M}$ Catechol solution. Change in absorbance was recorded in a spectrophotometer at $495 \mathrm{~nm}$ at an interval of $30 \mathrm{sec}$ for $5 \mathrm{~min}$. One unit of catechol oxidase is defined as the amount of enzyme that transforms $1 \mu \mathrm{m}$ of dihydrophenol to $1 \mu \mathrm{m}$ of quinine per minute under the assay conditions.

\section{Ascorbate peroxidase}

Ascorbate peroxidase activity was measured using the method described by Nakano and Asada (1981). Reaction mixture $(3 \mathrm{ml})$ containing potassium phosphate buffer $(50 \mathrm{mM}, \mathrm{pH} 7)$, ascorbic acid $(5 \mathrm{mM})$, and EDTA $(1 \mathrm{mM})$ was added with $0.1 \mathrm{ml}$ of enzyme extract. $\mathrm{H}_{2} \mathrm{O}_{2}(1 \mathrm{mM})$ was added to initiate the reaction. Decrease in absorbance was recorded in a spectrophotometer at $290 \mathrm{~nm}$ and enzyme activity was calculated by using the extinction coefficient of ascorbate $\left(2.8 \mathrm{mM}^{-1} \mathrm{~cm}^{-}\right.$ ${ }^{1}$ ). The enzymatic activity can be expressed as $\mathrm{U} \mathrm{ml}^{-1}$ of enzyme extract.

\section{Glutathione Reductase}

Glutathione reductase activity was assayed as per the method described by David and Richard (1983). The decrease in absorbance due to reduction of oxidized glutathione by the enzyme was observed in a spectrophotometer at $340 \mathrm{~nm}$. Enzyme extract $(0.1 \mathrm{ml})$ was mixed with $1 \mathrm{ml}$ of potassium buffer $(0.12 \mathrm{M}, \mathrm{pH} 7.2), 0.1 \mathrm{ml}$ of EDTA, $0.1 \mathrm{ml}$ of sodium azide and $0.1 \mathrm{ml}$ of oxidized glutathione. The volume was made up to $2 \mathrm{ml}$ with water. This mixture was kept at room temperature for 3 minutes and $0.1 \mathrm{ml}$ of NADPH was added to initiate the reaction. The absorbance at 340nm was recorded at intervals of 15 seconds for 2 minutes.

\section{Statistical analysis}

All the assays were performed in triplicates $(n=3)$ and the data shown as mean \pm SD. The data so obtained was subjected to analysis of variance (ANOVA) for significant variance, Correlation using the Microsoft Excel, 2016. All the curves were also made in Microsoft excel, 2016. 


\section{Results}

Higher altitudes have effect on the protein content and enzyme activities. The protein content has a significant $(\mathrm{p}<0.05)$ rise with increasing altitude (Table1, Fig. 1A). Activity for Catalase and Peroxidase was observed highest in Joshimath population (1986m), for Superoxide dismutase and Ascorbate peroxidase in Pipalkoti population (1339m) while Polyphenol and Glutathione reductase in Gopeshwar $(1488 \mathrm{~m})$ and Srinagar $(606 \mathrm{~m})$ population respectively. Negative correlation was observed in the SOD activity $(\mathrm{r}=-0.321)$ with the altitude, strong positive correlation was observed in POD $(\mathrm{r}=0.984)$, CAT $(\mathrm{r}=0.932)$ and $\mathrm{GR}(\mathrm{r}=0.963)$ activity while weak positive correlation was reported for PPO $(\mathrm{r}=0.552)$ and APX $(\mathrm{r}=0.670)$ (Table 2).

Table 1. Antioxidant activity of enzymes at different altitudes in Coleus forskohlii

\begin{tabular}{lccccccc}
\hline & \multicolumn{7}{c}{ Antioxidant Enzymes } \\
\hline Location & Altitude & $\begin{array}{c}\text { SOD } \\
\left(\mathbf{U m g}^{-1} \mathbf{F W}\right)\end{array}$ & $\begin{array}{c}\text { CAT } \\
\left(\mathbf{U m g}^{-1} \mathbf{F W}\right)\end{array}$ & $\begin{array}{c}\text { POD } \\
\left(\mathbf{U L}^{-1}\right)\end{array}$ & $\begin{array}{c}\text { PPO } \\
\left(\mathbf{U m g}^{-1} \mathbf{F W}\right)\end{array}$ & $\begin{array}{c}\text { APX } \\
\left(\mathbf{U m l}^{-1}\right)\end{array}$ & $\begin{array}{c}\text { GR } \\
\left(\mathbf{U m l}^{-1}\right)\end{array}$ \\
Srinagar & 606 & $0.252 \pm 0.02$ & $23.6 \pm 0.07$ & $326 \pm 0.62$ & $1.78 \pm 0.04$ & $1.03 \pm 0.12$ & $7.23 \pm 0.21$ \\
Rudraprayag & 727 & $0.240 \pm 0.03$ & $24.8 \pm 0.03$ & $359 \pm 0.78$ & $1.88 \pm 0.06$ & $1.25 \pm 0.09$ & $8.19 \pm 0.16$ \\
Pipalkoti & 1339 & $0.262 \pm 0.02$ & $25.6 \pm 0.06$ & $431 \pm 0.88$ & $1.96 \pm 0.03$ & $1.53 \pm 0.06$ & $12.54 \pm 0.13$ \\
Gopeshwar & 1488 & $0.260 \pm 0.05$ & $26.4 \pm 0.01$ & $476 \pm 0.97$ & $2.03 \pm 0.02$ & $1.28 \pm 0.05$ & $14.46 \pm 0.15$ \\
Joshimath & 1986 & $0.225 \pm 0.02$ & $26.6 \pm 0.02$ & $510 \pm 0.89$ & $1.89 \pm 0.07$ & $1.39 \pm 0.04$ & $14.95 \pm 0.12$ \\
\hline
\end{tabular}

Table 2. Correlation between antioxidant enzyme and altitude

\begin{tabular}{lrrrrrrrr}
\hline & Altitude & \multicolumn{1}{c}{ SOD } & CAT & POD & PPO & APX & GR & Protein \\
\hline Altitude & 1.000 & & & & & & & \\
SOD & -0.321 & 1.000 & & & & & & \\
CAT & 0.932 & -0.200 & 1.000 & & & & & \\
POD & 0.984 & -0.238 & 0.976 & 1.000 & & & & \\
PPO & 0.552 & 0.402 & 0.775 & 0.674 & 1.000 & & & \\
APX & 0.670 & 0.020 & 0.713 & 0.664 & 0.633 & 1.000 & & \\
GR & 0.963 & -0.091 & 0.965 & 0.989 & 0.742 & 0.685 & 1.000 & \\
Protein & 0.966 & -0.389 & 0.925 & 0.972 & 0.534 & 0.493 & 0.937 & 1.000 \\
\hline
\end{tabular}

Superoxide dismutase activity was found to be least affected by the altitude. Highest activity was observed in the Pipalkoti $\left(0.262 \pm 0.02 \mathrm{Umg}^{-1} \mathrm{FW}\right)$ and Gopeshwar population $\left(0.260 \pm 0.05 \mathrm{mg}^{-1} \mathrm{FW}\right)$ while a slight drop in the SOD activity was observed in the Joshimath population as compared to other populations (Fig. 1B). Catalase activity was also observed to be increasing with the altitude but no significant increase was observed. Highest activity of Catalase was observed in Joshimath population (26.6 $\left.\pm 0.02 \mathrm{Umg}^{-1} \mathrm{FW}\right)$ (Fig. 1C). Activity of 
Peroxidase reported with a significant increase over the altitudes and highest value was observed in Joshimath population $\left(510 \pm 0.89 \mathrm{UL}^{-1}\right)$ while lowest value was observed in Srinagar population (326 $\mathrm{Umg}^{-1}$ ) (Fig. 1D). Polyphenol oxidase activity was found highest in Gopeshwar population $\left(2.03 \pm 0.02 \mathrm{Umg}^{-1} \mathrm{FW}\right)$ which further decreases in Joshimath population $\left(1.89 \pm 0.07 \mathrm{Umg}^{-1} \mathrm{FW}\right)$ while lowest activity was recorded in Srinagar population $(1.78 \pm 0.04$ $\mathrm{Umg}^{-1} \mathrm{FW}$ ) (Fig. 1E). Ascorbate peroxidase activity was observed to be increasing initially with the increasing altitude with lowest activity in the Srinagar population $\left(1.03 \pm 0.12 \mathrm{Uml}^{-1}\right)$ and highest activity in Pipalkoti population $\left(1.53 \pm 0.06 \mathrm{Uml}^{-1}\right)$ the activity decreases afterwards in Gopeshwar $\left(1.28 \pm 0.05 \mathrm{Uml}^{-1}\right)$ and Joshimath $\left(1.39 \pm 0.04 \mathrm{Umg}^{-1}\right)$ population (Fig. 1F). Highest activity of Glutathione reductase was observed in the Joshimath population $\left(14.95 \pm 0.12 \mathrm{Uml}^{-1}\right)$ which decreases at lower altitudes and lowest activity was found in Srinagar population $\left(7.23 \pm 0.13 \mathrm{Uml}^{-1}\right)$ (Fig. 1G).

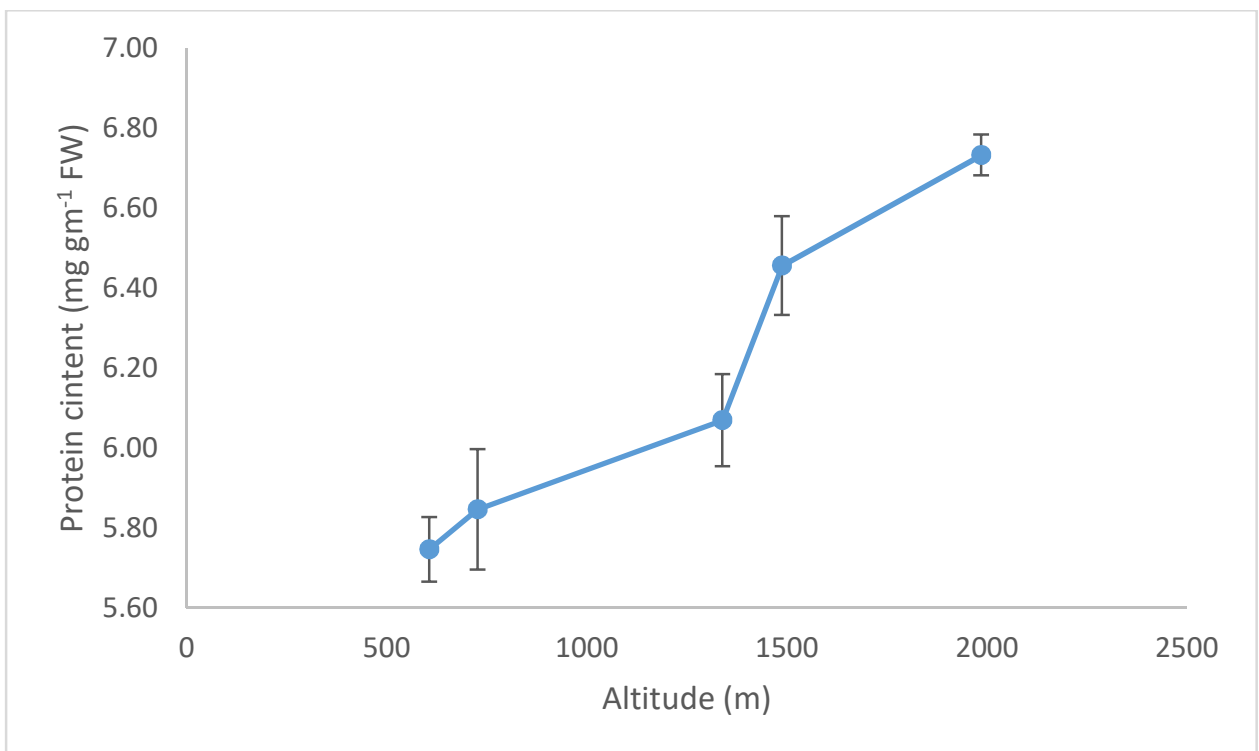

(A) 


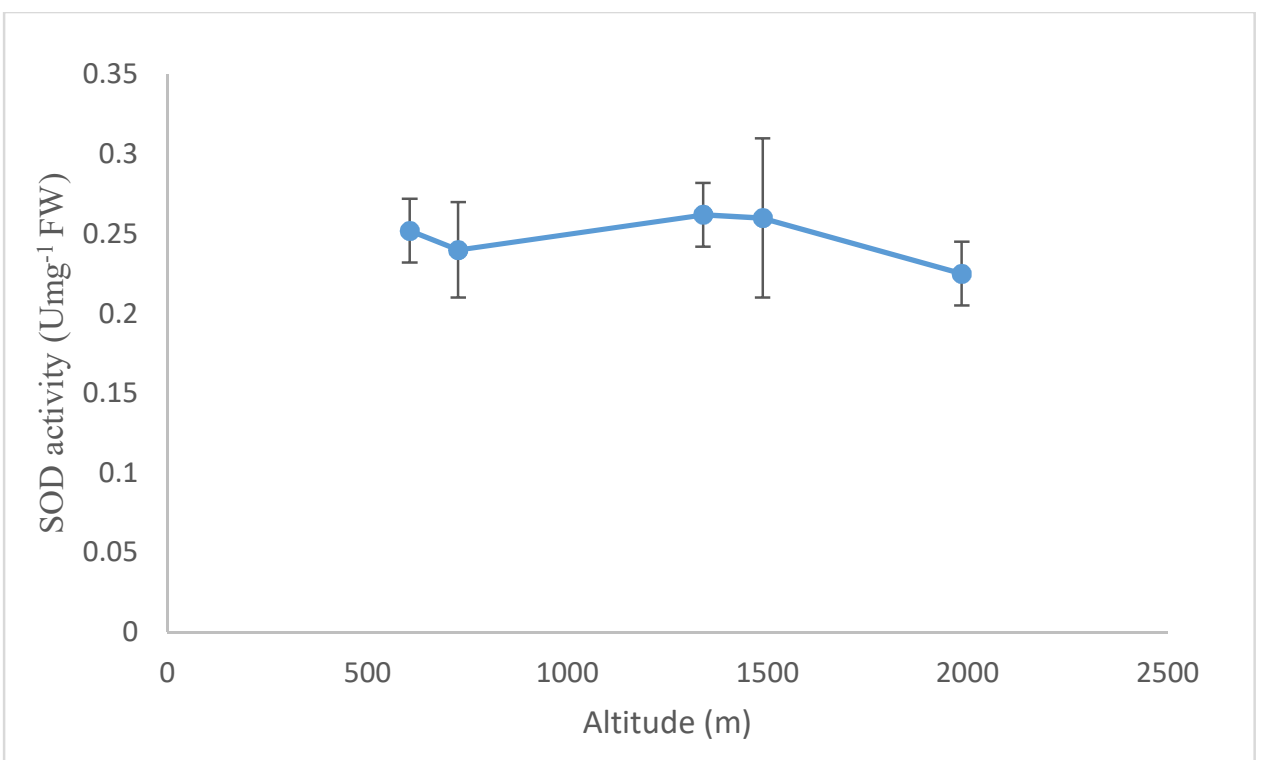

(B)

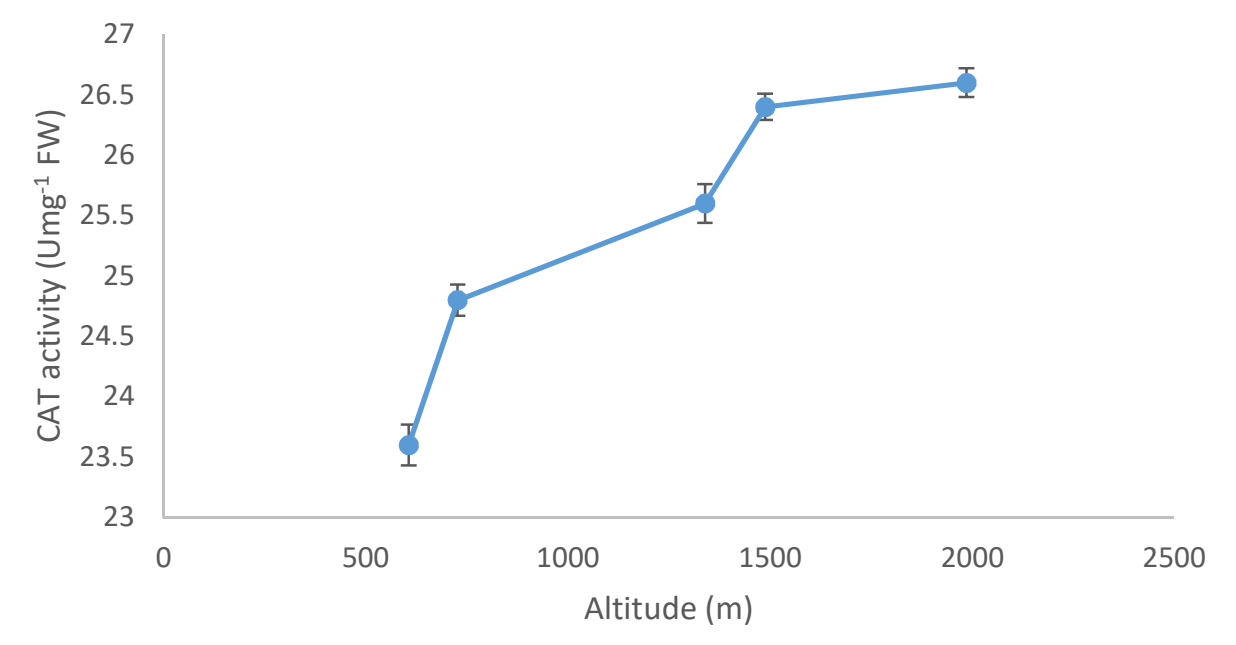

(C)

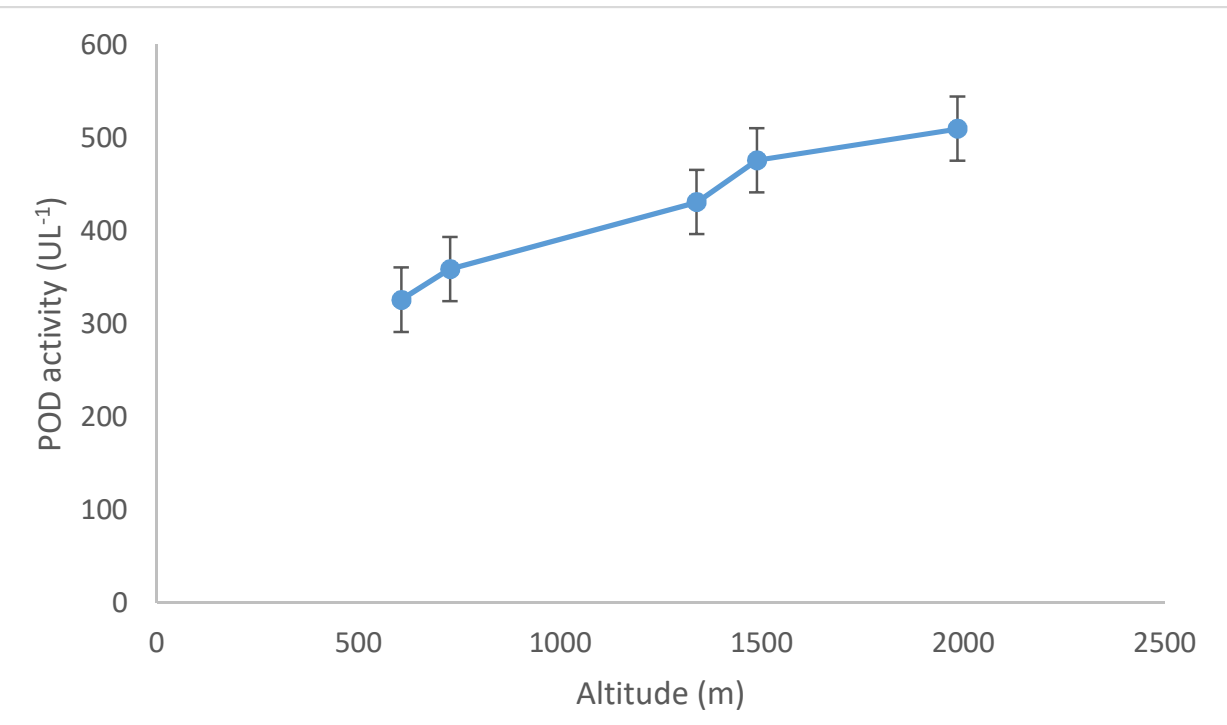

(D) 


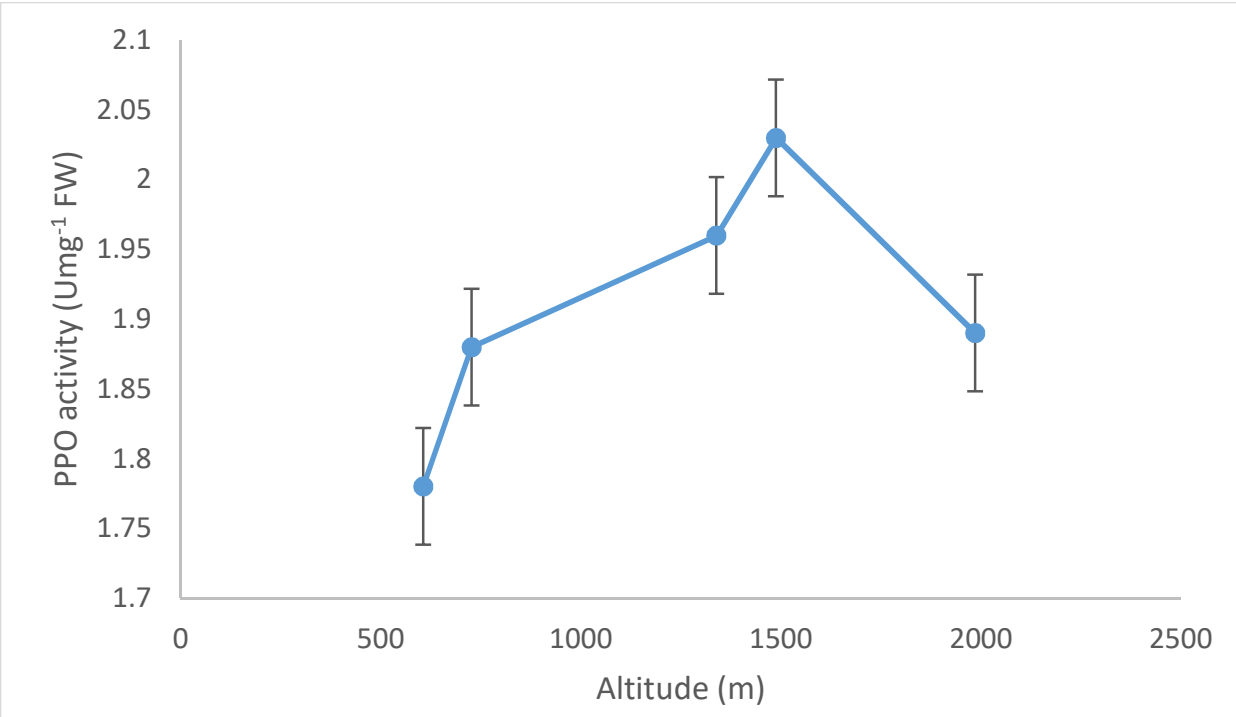

(E)

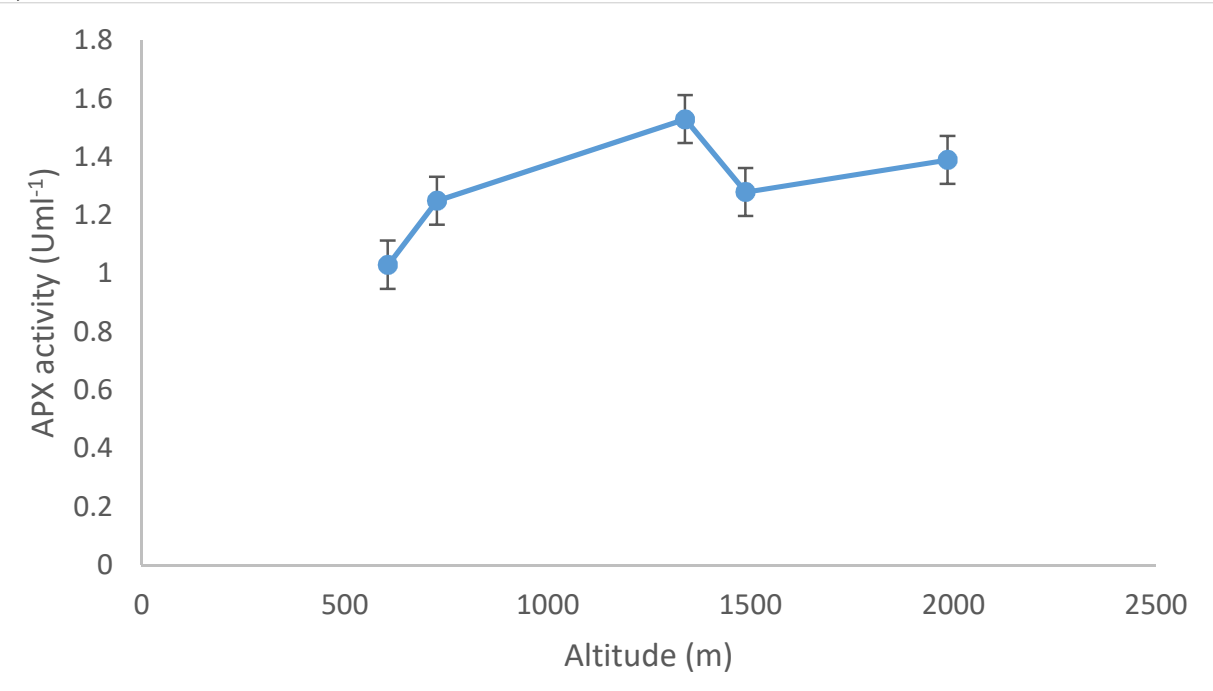

(F)

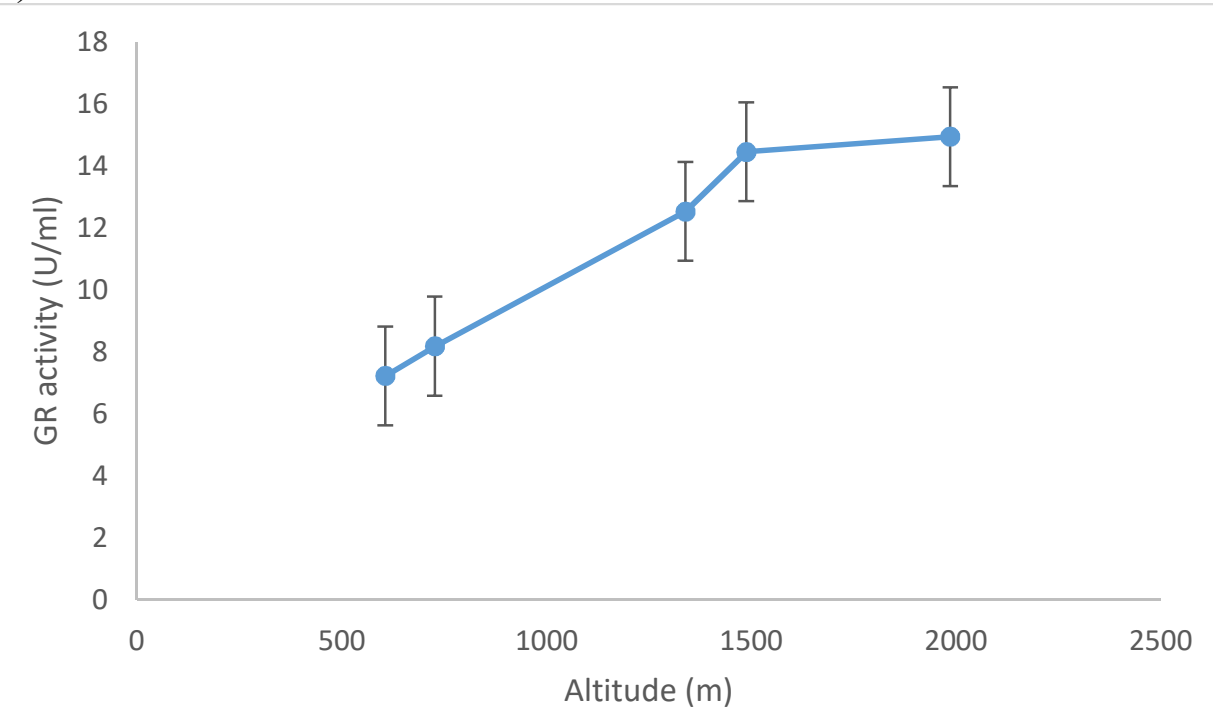

(G) 
Fig. 1. Pattern of protein content and enzymatic activities across altitudes (A) Protein content, (B) SOD, (C) CAT, (D) POD, (E) PPO, (F) APX, (G) GR

\section{Discussion}

Plant growth is affected by various factors like temperature, precipitation, light intensity and radiation intensity. With the increasing altitude all these factors also change which affects the plant growth. In order to get adapted to the changing environmental conditions many physiological and biochemical changes occur in the plant. Effect of environmental factors affecting the physiological and biochemical changes have been studied in many plants (Cui et al., 2018; Ahmad et al., 2016; Aghaei et al., 2009; Qin et al., 2009; Li et al., 2014).

In the present study the plant samples were collected from five different altitudes to analyze the effect of changing altitude on the activity of antioxidant enzymes. High protein content in the samples of high altitudes can be attributed to the increased cellular metabolism to cope up with oxidative stress as well as to reduce the osmotic potential under stress (Basu et al., 2007). In the present study high protein content in C. forskohlii was observed in the plant samples of higher altitude. The increase in protein content under stress conditions may raise the functional protein content to ensure cellular metabolism. With the increasing altitude oxidative stress and intensity of UV radiation increases (Reiger et al., 2008) that leads to generation of more reactive oxygen species. In order to combat the oxidative damage due to the ROS plats have developed defense system which involves antioxidant enzymes also. SOD catalyzes the conversion of superoxide anion radicals to hydrogen peroxide and acts as a primary ROS scavenger, an increase in SOD activity indicates towards higher scavenging of superoxide anion radicals (Asada et al., 1999; Foyar et al., 2005). CAT plays an important role in defense against oxidative stress damage as it catalyzes the decomposition of hydrogen peroxide to water and oxygen. With their ability to scavenge the free radicals these enzymes help in maintaining the redox state in the plant cell. In the present study very little rise in the levels of SOD and CAT indicates towards better adaptability of C. forskohlii and the levels of SOD and CAT are enough to scavenge the deteriorating effect of superoxide anions and hydrogen peroxide. Peroxidase does the similar function of scavenging $\mathrm{H}_{2} \mathrm{O}_{2}$ as Catalase by using electron donors. In the present study the peroxidase activity rises concomitantly with the increasing altitude POD can scavenge the ROS in early senescence and induce lipid peroxidation in late senescence. The opposite trends of CAT and POD may be an adaptive adjustment towards the 
environment. Positive correlation was reported in Polyphenol oxidase and Ascorbate peroxidase activity with the increasing altitude. Higher APX activity at high altitudes may be to scavenge the plants from high $\mathrm{H}_{2} \mathrm{O}_{2}$ level (Kaur et al., 2016). High intensity of UV radiation and the low temperature leads to a higher oxidative stress with $\mathrm{H}_{2} \mathrm{O}_{2}$ production at higher altitudes (Georgieva et al., 2014). The increasing activity of GR and PPO at higher altitude may be attributed to the defense mechanism of plant by $\mathrm{H}_{2} \mathrm{O}_{2}$ decomposition. The increasing activity of antioxidant enzymes with the increasing altitude have been reported earlier also (Khan et al., 2016).

\section{Conclusion}

This study provides supporting evidence for the higher antioxidant activity of Coleus forskohlii. Enhanced activity of SOD, CAT, POD, PPO, APX and GR at higher altitudes reflects higher ROS scavenging potential of $C$. forkohlii population from high altitudes. Thus the population of $C$. forskohlii from a higher altitude can be used a source of high antioxidants.

\section{Acknowledgement}

We gratefully acknowledge the financial support from Uttarakhand Biotechnology Council (UCB), Govt of Uttarakhand, UCB/R\&D Project/2017-47.

\section{References}

Aghaei K, Ehsanpour AA, Komatsu S (2009). Potato responds to salt stress by increased activity of antioxidant enzymes. Journal of Integrative Plant Biology., 51(12), 1095-103.

Ahmad KS, Hameed M, Fatima S, Ashraf M, Ahmad F, Naseer M, Akhtar N (2016). Morphoanatomical and physiological adaptations to high altitude in some Aveneae grasses from Neelum Valley, Western Himalayan Kashmir. Acta physiologiae plantarum., 38(4):93.

Ammon HP, Müller AB (1985). Forskolin: from an ayurvedic remedy to a modern agent. Planta medica., (06):473-477.

Asada K (1999). The water-water cycle in chloroplasts: scavenging of active oxygens and dissipation of excess photons. Annual review of plant biology. 50(1):601-639. 
Barry RG (1992). Mountain weather and climate. Psychology Press.

Basu PS, Berger JD, Turner NC, Chaturvedi SK, Ali M, Siddique KH (2007). Osmotic adjustment of chickpea (Cicer arietinum) is not associated with changes in carbohydrate composition or leaf gas exchange under drought. Annals of Applied Biology., 150(2):217225.

Chandel KP, Sharma N. Micropropagation of Coleus forskohlii (Willd.) Briq. InHigh-Tech and Micropropagation VI 1997 (pp. 74-84). Springer, Berlin, Heidelberg.

Chen Q, Zhang M, and Shen S (2010). Effect of salt on malondialdehyde and antioxidant enzymes in seedling roots of Jerusalem artichoke (Helianthus tuberosus L.). Acta Physiologiae Plantarum. 33(2): 273-278.

Cho UH, Seo NH (2005). Oxidative stress in Arabidopsis thaliana exposed to cadmium is due to hydrogen peroxide accumulation. Plant Science., 168(1):113-120.

Cui G, Wei X, Degen AA, Wei X, Zhou J, Ding L, Shang Z, Liu S, Long R (2016). Troloxequivalent antioxidant capacity and composition of five alpine plant species growing at different elevations on the Qinghai-Tibetan Plateau. Plant Ecology \& Diversity., 9(4):387-96.

Foyer CH, Noctor G (2005). Oxidant and antioxidant signalling in plants: a re-evaluation of the concept of oxidative stress in a physiological context. Plant, Cell \& Environment., 28(8):1056-1071.

Georgieva E, Petrova D, Yordanova Z, Kapchina-Toteva V, Cellarova E, Chaneva G (2014). Influence of cryopreservation on the antioxidative activity of in vitro cultivated Hypericum species. Biotechnology \& Biotechnological Equipment., 28(5):863-870.

Huang B, DaCosta M, Jiang Y (2014). Research advances in mechanisms of turfgrass tolerance to abiotic stresses: from physiology to molecular biology. Critical reviews in plant sciences., (2-3):141-189.

Kaur T, Bhat R, Vyas D (2016). Effect of contrasting climates on antioxidant and bioactive constituents in five medicinal herbs in Western Himalayas. Journal of Mountain Science., 13(3):484-492. 
Khan MN, Mobin M, Abbas ZK, ALMutairi KA (2016). Impact of varying elevations on growth and activities of antioxidant enzymes of some medicinal plants of Saudi Arabia. Acta Ecologica Sinica., 36(3), 141-148.

Khatun S, Chatterjee NC, Cakilcioglu U (2011). Antioxidant activity of the medicinal plant Coleus forskohlii Briq. African Journal of Biotechnology., 10(13):2530-2535.

Kurian A, Sankar MA (2007). Medicinal plants. New India Publishing.

Lantemona H, Abadi AL, Rachmansyah A, Pontoh J. Impact of altitude and seasons to volume, brix content, and chemical composition of aren sap in north Sulawesi (2013). IOSR Journal of Environmental Science, Toxicology and Food Technology., 4(2):42-48.

Li X, Yang Y, Ma L, Sun X, Yang S, Kong X, Hu X, Yang Y (2014). Comparative proteomics analyses of Kobresia pygmaea adaptation to environment along an elevational gradient on the central Tibetan Plateau. PloS one., 2014 9(6): e98410.

Misra HP, Fridovich I. The role of superoxide anion in the autoxidation of epinephrine and a simple assay for superoxide dismutase. Journal of Biological chemistry. 1972 May 25;247(10):3170-5.

Møller IM, Jensen PE, Hansson A (2007). Oxidative modifications to cellular components in plants. Annu. Rev. Plant Biol., 58:459-481.

Noctor G, and Foyer CH, (1998). Ascorbate and glutathione: keeping active oxygen under control," Annual Review of Plant Biology., 49, 249-279.

Patil S, Hulamani NC, Rokhade AK (2001). Peformance of genotypes of Coleus forskohlii Briq. for growth, yield and essential oil content. Indian Perfumer., 45(1):17-22.

Qin J, Liu Q (2009). Impact of seasonally frozen soil on germinability and antioxidant enzyme activity of Picea asperata seeds. Canadian journal of forest research., 39(4), 723-30.

Rieger G, Müller M, Guttenberger H, and Bucar F (2008). Influence of altitudinal variation on the content of phenolic compounds in wild populations of Calluna vulgaris, Sambucus nigra, and Vaccinium myrtillus. Journal of agricultural and food chemistry., 56, 90809086.

Valdes LJ, Mislankar SG, Paul AG (1987). Coleus barbatus (C. forskohlii) (Lamiaceae) and the potential new drug forskolin (Coleonol). Economic botany., 41(4):474. 
Zaefyzadeh M, Quliyev RA, Babayeva SM, and Abbasov MA (2009). The effect of the interaction between genotypes and drought stress on the superoxide dismutase and chlorophyll content in durum wheat landraces. Turkish Journal of Biology., 33(1):1-7. 